\title{
PENGEMBANGAN MEDIA GAMBAR “BE A SCIENTIST" DENGAN PROGRAM ADOBE FLASH CS3 UNTUK PEMBELAJARAN SEJARAH
}

\author{
Dina Fitriana \\ (Dinas Pendidikan Pontianak) \\ Email: dinafitriana.df81@gmail.com
}

\begin{abstract}
ABSTRAK
Penelitian ini bertujuan untuk: (1) mengembangkan media gambar "Be a Scientist" dengan program Adobe Flash CS3 untuk pembelajaran Sejarah kelas X SMA; (2) mengetahui kelayakan media gambar yang dikembangkan. Jenis penelitian ini adalah research and development. Subjek uji coba dalam penelitian ini sejumlah 52 peserta didik. Teknik pengumpulan data yang digunakan dalam penelitian ini terdiri atas: wawancara, observasi, lembar penilaian, dan dokumentasi. Prosedur analisis data yang digunakan untuk menentukan kelayakan produk yang dikembangkan adalah: (1) data yang diperoleh dari lembar penilaian dikonversi ke skala 100; (2) data dianalisis dengan statistik deskriptif; (3) data dianalisis menggunakan penilaian acuan patokan (PAP); (4) seluruh data dikonversi ke dalam skala 100 untuk menentukan kriteria kelayakan pada masing-masing aspek. Hasil penilaian menunjukkan bahwa skor media sebagai berikut: (1) aspek materi, penilaian layak dengan skor 79,4 dan kategori penilaian "B" (baik). (2) aspek media, penilaian layak dengan skor 81,6 dan kategori penilaian "B" (baik). Dengan demikian, dapat disimpulkan bahwa media gambar "Be a Scientist" yang dikembangkan layak digunakan untuk pembelajaran Sejarah di kelas X SMA pada materi pengaruh agama dan kebudayaan Islam di Indonesia.
\end{abstract}

Kata Kunci: media gambar "Be a Scientist”, pembelajaran sejarah, Adobe Flash CS3.

\begin{abstract}
ABSTRACK
This research aims to: (1) develop picture media "Be a Scientist" using Adobe Flash CS3 program for history instruction of grade-X of senior high school; (2) to test the feasibility of the developed picture media.This research is a research and development study. The subjects were 52 students. The data collection techniques used in this research consisted of: the interview, the observation, the assessment sheet, and documentation, to show the evidence of the research process. The data analysis procedure used to determine the eligibility of the products developed were: (1) the data obtained from the assessment sheet were converted to a scale of 100; (2) the data were analyzed with descriptive statistics; (3) the data were analyzed using the reference benchmark assessment (PAP); (4) all data were converted into a scale of 100 to determine the eligibility criteria for each aspect.The assessment results show that the media scores are as follows: (1) the material aspect is in an adequate category with a score of 79.4 and assessment category 'B' (good); (2) the media aspect is in an adequate category with a score of 81.6 and assessment category 'B' (good). Thus, it can be concluded that the developed picture media "Be a Scientist" using Adobe Flash CS3 program for history instruction of grade-X of senior high school with the topic of the influence of religion and culture of Islam in Indonesia.
\end{abstract}

Keywords: picture media "Be A Scientist", history instruction, Adobe Flash CS3. 


\section{Pendahuluan}

Pendidikan merupakan kebutuhan setiap manusia dan berlangsung sepanjang masa. Pendidikan sangat penting karena tanpa pendidikan suatu bangsa akan sulit untuk maju, bahkan akan menjadi bangsa yang terbelakang. Oleh karena itu, pendidikan harus diarahkan untuk menghasilkan manusia yang berkualitas, yang mampu bekerjasama di kancah internasional. Selain itu, pendidikan juga diharapkan dapat membentuk manusia yang memiliki budi pekerti dan moral yang luhur. Undang-undang (UU) No 20 Tahun 2003 tentang sistem pendidikan nasional menyebutkan bahwa fungsi pendidikan nasional yaitu mengembangkan kemampuan dan membentuk watak serta peradaban bangsa yang bermartabat dalam rangka mencerdaskan kehidupan bangsa, bertujuan untuk berkembangnya potensi peserta didik agar menjadi manusia yang bertakwa kepada Tuhan Yang Maha Esa, berakhlak mulia, sehat, berilmu, cakap, kreatif, mandiri dan menjadi warga negara yang demokratis serta bertanggung jawab.

Proses pendidikan dimaksudkan untuk membantu peserta didik tumbuh dan berkembang secara maksimal dalam berbagai aspek kehidupan, sehingga peserta didik menjadi manusia dewasa yang mandiri, tidak tergantung pada orang lain. Oleh karena itu, proses pembelajaran di sekolah menjadi sangat penting dalam pencapaian tujuan tersebut. Hal ini termuat dalam Peraturan Menteri Pendidikan dan Kebudayaan (Permendikbud) Republik Indonesia No. 65 Tahun 2013 menjelaskan bahwa standar proses adalah standar nasional pendidikan yang berkaitan dengan pelaksanaan pembelajaran pada satuan pendidikan untuk mencapai kompetensi lulusan. Standar proses meliputi perencanaan proses pembelajaran, pelaksanaan proses pembelajaran, penilaian hasil pembelajaran, dan pengawasan proses pembelajaran.

Lebih lanjut dijelaskan dalam lampiran permendikbud tersebut bahwa standar proses mencakup tiga unsur. Pertama, Perencanaaan proses pembelajaran yang meliputi Silabus dan Rencana Pelaksanaan Pembelajaran (RPP). Silabus memuat Standar Kompetensi (SK), Kompetensi Dasar (KD), indikator pencapaian kompetensi, tujuan pembelajaran, materi ajar, alokasi waktu, metode pembelajaran, kegiatan pembelajaran, penilaian hasil belajar, dan sumber belajar. Rencana Pelaksanaan Pembelajaran (RPP) memuat identitas mata pelajaran, Standar Kompetensi (SK), Kompetensi Dasar (KD), indikator pencapaian kompetensi, tujuan pembelajaran, materi ajar, alokasi waktu, metode pembelajaran, kegiatan pembelajaran, penilaian hasil belajar, dan sumber belajar. Kedua, Pelaksanaan proses pembelajaran yang meliputi kegiatan pendahuluan, kegiatan inti dan kegiatan penutup. Ketiga, Penilaian yang dilakukan oleh guru terhadap hasil pembelajaran untuk mengukur tingkat pencapaian kompetensi peserta didik, serta digunakan sebagai bahan penyusunan laporan kemajuan hasil belajar, dan memperbaiki proses pembelajaran.

Ilmu Pengetahuan Sosial Merupakan mata pelajaran bidang keilmuwan yang bertujuan untuk membentuk warga negara yang baik, Seperti yang dikemukakan Nursid (2008:11) bahwa Ilmu Pengetahuan Sosial (IPS) bertujuan membina anak didik menjadi warga negara yang baik, memiliki pengetahuan, keterampilan dan kepedulian sosial yang berguna bagi dirinya sendiri serta bagi masyarakat dan negara.

Salah satu komponen Ilmu Pengetahuan Sosial (IPS) adalah sejarah. Menurut Suhartono (2010:2) sejarah adalah ilmu pengetahuan dari subjek yang definit disyaratkan oleh metode yang bebas dan

Dina Fitriana, Pengembangan Media Gambar "Be a Scientist" dengan Program Adobe Flash CS3 untuk Pembelajaran Sejarah 
teratur atau proses dan diatur dalam ketentuan yang dapat diterima. Sejarah merupakan salah satu cabang dari humaniora yang mengkaji secara sistematis keseluruhan perkembangan masyarakat serta kemanusiaan di masa lampau beserta kejadian-kejadian yang dianggap berpengaruh terhadap kehidupan manusia yang kemudian dinilai secara kritis untuk selanjutnya dijadikan pedoman bagi penilaian dan penentuan keadaan pada masa sekarang serta arah proses ke masa depan.

Berdasarkan uraian tersebut dapat dikatakan bahwa hakikat pembelajaran sejarah tidak hanya sekedar mengingat dan memahami konsep, tetapi juga melalui observasi dan dokumentasi. Observasi merupakan pengumpulan data yang diperoleh dari pengamatan. Data yang diperoleh berupa kegiatan, perilaku tindakan serta keseluruhan kemungkinan yang merupakan bagian dari pengalaman manusia. Dokumentasi merupakan pengumpulan informasi yang berhubungan dengan masalah penelitian dan kemudian mempelajari buku-buku untuk memperoleh informasi yang bersifat teoritis berkenaan dengan masalah yang akan dipecahkan. Dengan demikian dapat diperoleh data yang sesuai untuk memecahkan masalah yang diajukan. Observasi dan dokumentasi ini merupakan kegiatan studi yang dilakukan para ilmuwan (scientist).

Cara kerja para ilmuwan (scientist) untuk memperoleh pengetahuan tentang sejarah, secara khusus ditujukan untuk mendapatkan informasi tentang waktu dan peristiwa yang berhubungan dengan suatu artefak peninggalan masa lalu. Seorang ilmuwan (scientist) selalu bersifat objektif dan jujur dengan mengesampingkan perasaan/emosinya.

Langkah-langkah yang selalu dilakukan oleh seorang scientist untuk memperoleh ilmu, secara berturut-turut mulai dengan mengamati (observing), menanya (questioning), menalar (associating), mencoba (experimenting), membentuk jejaring (networking). Jika dalam proses pembelajaran sejarah peserta didik melakukan tahap-tahap seperti scientist, diharapkan pembelajaran sejarah akan menjadi lebih bermakna. Hal ini dikarenakan peserta didik menemukan sebuah konsep berdasarkan temuannya sendiri. Langkah-langkah ini dalam kurikulum 2013 disebut pendekatan Scientific.

Kurikulum 2013 yang segera diberlakukan secara nasional menekankan pada dimensi paedagogik modern dalam pembelajaran, yaitu menggunakan pendekatan ilmiah (scientific approach). Untuk mewujudkan tujuan pembelajaran sejarah yang sesuai dengan Kurikulum 2013, maka perlu dikembangkan suatu strategi pembelajaran dengan pendekatan Scientific. Dalam penelitian ini, pendekatan tersebut diwujudkan dalam bentuk media gambar "Be a Scientist" dengan program Adobe Flash CS3 untuk pembelajaran sejarah kelas X SMA.

Media dalam proses belajar mengajar cenderung diartikan sebagai alat grafis, photografis, atau elektronis untuk menangkap, memproses, dan menyusun kembali informasi visual atau verbal (Azar, 2011:3). Media pembelajaran adalah alat bantu, baik berupa alat-alat elektronik, gambar, peraga, buku dan lain-lain yang digunakan guru dalam menyalurkan isi pembelajaran (Kasful \& Hendra, 2011:101). Media pembelajaran adalah sebagai penyampaian pesan (the carries of messages) dari beberapa sumber saluran ke penerimaan pesan (the receiver of the messages) (Trianto, 2012:235). Pengertian selanjutnya juga dikemukan oleh Zainal (2013:50) yakni media pembelajaran adalah segala sesuatu yang dapat digunakan untuk menyalurkan pesan dan merangsang proses belajar pada si pembelajar.

Dina Fitriana, Pengembangan Media Gambar "Be a Scientist" dengan Program Adobe Flash CS3 untuk Pembelajaran Sejarah 
Media gambar "Be a Scientist" dengan program Adobe Flash CS3 adalah suatu media pembelajaran yang melatih peserta didik untuk meningkatkan kemampuan berfikir sampai dapat menemukan sebuah konsep. Media pembelajaran digunakan dalam pelaksanaan pendidikan untuk mengintensifkan proses pembelajaran. Dengan media pembelajaran ini, diharapkan dapat meningkatkan kemampuan berfikir peserta didik secara konkrit seperti seorang scientist dalam memperoleh ilmu.

Terdapat tiga variasi penggunaan media dalam kegiatan pembelajaran yaitu media visual, media audio, dan media audiovisual. Media gambar merupakan salah satu media pembelajaran yang termasuk dalam media visual. Penyajian media gambar dengan program Adobe Flash CS3 dapat dilengkapi dengan aspek gerak dan aspek suara, sehingga media pembelajaran yang dihasilkan berupa media pembelajaran audio-visual. Karakteristik program Adobe Flash CS3 yaitu tidak hanya menyajikan materi yang dapat dilihat dan dibaca tetapi juga menyajikan video yang dapat dilihat dan didengar.

Dalam pembelajaran sejarah, media gambar "Be a Scientist" dengan program Adobe Flash CS3 dapat mengarahkan peserta didik untuk menemukan sebuah konsep Sejarah berdasarkan langkahlangkah sesuai dengan yang dilakukan seorang scientist. Tujuan pembuatan media gambar "Be a Scientist" dengan program Adobe Flash CS3, agar peserta didik dapat belajar Sejarah melalui proses penemuaan konsep. Media ini disusun sesuai dengan Peraturan Menteri Pendidikan Nasional (Permendiknas) No. 65 Tahun 2013 mengenai Standar Proses.

Perbedaan antara media gambar " $B e$ a Scientist" dengan program Adobe Flash CS3 dengan media gambar lain terletak pada langkah-langkah pelaksanaannya. Langkah- langkah pelaksanaannya disusun sesuai dengan konsep pendekatan Scientific yang dikembangkan dalam Kurikulum 2013. Langkah-langkah tersebut meliputi mengamati (observing), menanya (questioning), menalar (associating), mencoba (experimenting), membentuk jejaring (networking). Oleh karena itu, Media gambar "be a scientist" dengan program Adobe Flash CS3 ini merupakan cara, langkah-langkah, sarana pembelajaran, dan sarana bagi peserta didik untuk dapat menemukan suatu konsep Sejarah berdasarkan langkah ilmiah.

Penggunaan gambar "Be a Scientist" dengan program Adobe Flash CS3 sebagai media pembelajaran masih sangat jarang dilakukan oleh guru sejarah. Penggunaan media khusus untuk komunikasi ilmiah, seperti media gambar "Be a Scientist" dengan program Adobe Flash CS3 memiliki keuntungan yaitu dapat membantu proses berpikir secara konkrit dan mengurangi respon yang kurang bermanfaat. Selain itu, media gambar ini juga dapat menambah frekuensi belajar siswa karena penggunaannya mudah dan menyenangkan, sehingga siswa dapat belajar sendiri/mandiri lebih mendalam mengenai materi yang dipelajari di sekolah.

Peraturan Pemerintah (PP) Republik Indonesia No.17 Tahun 2010 tentang Pengelolaan dan penyelenggaraan pendidikan menjelaskan pendidikan menengah umum berfungsi: (1) meningkatkan, menghayati dan mengamalkan nilai-nilai keimanan, akhlak mulia dan kepribadian luhur; (2) meningkatkan, menghayati, dan mengamalkan nilai-nilai kebangsaan dan cinta tanah air; (3) mempelajari ilmu pengetahuan dan teknologi; meningkatkan kepekaan dan kemampuan mengapresiasi serta mengekspresikan keindahan, kehalusan dan harmoni; (5) menyalurkan bakat dan kemampuan di

Dina Fitriana, Pengembangan Media Gambar "Be a Scientist" dengan Program Adobe Flash CS3 untuk Pembelajaran Sejarah 
bidang olahraga, baik untuk kesehatan dan kebugaran jasmani maupun prestasi; (6) meningkatkan kesiapan fisik dan mental untuk melanjutkan pendidikan ke jenjang pendidikan tinggi dan/atau untuk hidup mandiri di masyarakat.

Selanjutnya, dijelaskan pada pasal 77 tujuan pendidikan menengah untuk membentuk peserta didik menjadi insan sebagai berikut: Pertama, beriman dan bertakwa kepada Tuhan Yang Maha Esa, berakhlak mulia, dan berkepribadian luhur; Kedua, berilmu, cakap, kritis, kreatif, inovatif; Ketiga, sehat, mandiri, dan percaya diri; keempat, toleran, peka sosial, demokratis dan bertanggung jawab.

Berdasarkan fungsi dan tujuan pendidikan menengah yang telah dikemukakan tersebut. Terlihat jelas bahwa pendidikan menengah haruslah memiliki strategi yang dapat menunjang ketercapaian fungsi dan tujuan tersebut. Strategi tersebut dapat berupa pola pengajaran yang dilakukan guru di dalam kelas. Dalam proses pembelajaran, media merupakan alat penunjang keberhasilan. Media pembelajaran dapat menjadi alat penyampaian materi yang dapat digunakan guru di dalam kelas.

Dewasa ini SMA yang ada di Yogyakarta sudah menggunakan media pembelajaran. Hasil wawancara pada saat prasurvey dibeberapa SMA, diperoleh informasi, media pembelajaran yang digunakan hanya buku Lembar Kerja Siswa (LKS). Sekolah tersebut adalah MAN 01 Yogyakarta, MAN Gandekan Bantul, dan SMA Negeri 01 Jetis. Pada sekolah tersebut menunjukkan bahwa media pembelajaran Sejarah yang digunakan didominasi oleh LKS. Media pembelajaran berbentuk audiovisual masih sangat minim digunakan.

MAN 01 Yogyakarta dalam proses pembelajaran sejarah di kelas $\mathrm{X}$ menggunakan LKS kreatif terbitan Pakarindo. MAN Gandekan Bantul juga menggunakan LKS yang sama. Dalam penyusunan dan penyajian materi, LKS tersebut menyesuaikan dengan kurikulum yang ditetapkan yaitu Kurikulum Tingkat Satuan Pendidikan (KTSP). Materi pembelajaran dalam buku Kreatif disajikan dengan berbagai perlengkapan antara lain pemahaman materi, kegiatan individu, kegiatan kelompok, uji kompetensi dan nilai karakter.

Prasurvey juga dilakukan di SMA Negeri 01 Jetis Bantul, yang juga dalam pembelajaran sejarah kelas $\mathrm{X}$ disekolah tersebut menggunakan LKS. LKS yang digunakan merupakan LKS Celcius terbitan CV. Grafita Dua tujuh. LKS ini disusun berdasarkan Kurikulum Tingkat Satuan Pendidikan (KTSP) tahun 2006 yang berwawasan karakter bangsa. LKS ini secara sistematis meliputi ringkasan materi, tugas dan lembar kerja, latihan soal mid semester dan akhir semester. Guru di sekolah tersebut sesekali menggunakan media pembelajaran berupa microsoft powerpoint buatan sendiri.

Berdasarkan data prasurvey tersebut, dapat diambil kesimpulan bahwa media pembelajaran berbentuk audio-visual masih jarang digunakan dalam proses pembelajaran sejarah. Selain itu, terlihat bahwa media pembelajaran yang digunakan hanya mementingkan ingatan dan pemahaman fakta tanpa mengarahkan peserta didik untuk melakukan tahap-tahap penemuan konsep sebagai yang dilakukan oleh scientist.

Media gambar "Be a Scientist" dengan program Adobe Flash CS3 diharapkan dapat memberikan sumbangan yang cukup berarti dalam mencerdaskan anak-anak bangsa yang sedang gencar memburu ilmu dibangku sekolah. Media ini diharapkan juga mampu membantu guru dalam penyampaian materi. Oleh karena itu, peneliti tertarik untuk mengembangkan media pembelajaran sejarah bentuk media gambar "Be a Scientist" dengan program

Dina Fitriana, Pengembangan Media Gambar "Be a Scientist" dengan Program Adobe Flash CS3 untuk Pembelajaran Sejarah 
Adobe Flash CS3 untuk pembelajaran sejarah siswa kelas X SMA. Mengingat bahwa media pembelajaran sejarah berbentuk media gambar "Be a Scientist" dengan program Adobe Flash CS3 untuk pembelajaran sejarah pada kelas X SMA belum banyak dikembangkan.

Berdasarkan paparan tersebut tujuan penelitian adalah untuk: (1) mengembangkan media gambar "Be a Scientist"dengan program Adobe Flash CS3 pada materi "pengaruh agama dan kebudayaan Islam di Indonesia" untuk pembelajaran sejarah kelas X SMA. (2) mengetahui kelayakan media gambar "Be a Scientist"dengan program Adobe Flash CS3dengan materi "pengaruh agama dan kebudayaan Islam di Indonesia" untuk proses pembelajaran sejarah kelas X SMA.

\section{Metode Penelitian}

Penelitian ini termasuk kedalam penelitian pengembangan atau dikenal dengan Research and Development (R\&D). Model pengembangan merupakan suatu usaha untuk mengembangkan suatu produk yang efektif berupa material pembelajaran, media dan strategi pembelajaran untuk digunakan di sekolah. Penelitian pengembangan dilakukan bukanlah untuk menguji suatu teori. Penelitian dan pengembangan berorientasi untuk mengembangkan dan memvalidasi produkproduk pendidikan.

Penelitian ini dirancang selama 6 bulan dimulai dari kurun waktu November 2013 sampai April 2014. Dalam kurun waktu ini terdapat beberapa langkah yaitu penelitian pendahuluan, perencanaan produk awal, uji coba kelompok kecil, revisi produk uji coba kelompok kecil, uji coba lapangan, revisi uji produk utama (produk jadi).

Langkah-langkah dalam penelitian pengembangan atau Research and Development $(\mathrm{R} \& \mathrm{D})$ yang digunakan dalam penelitian ini adalah adaptasi model pengembangan Borg \& Gall dan model pengembangan Sugiyono. Pada penelitian ini akan dikembangkan sebuah media pembelajaran berupa media gambar "Be a Scientist" dengan program Adobe Flash CS3 untuk pembelajaran sejarah kelas X SMA. Prosedur Pengembangan.

Penjelasan yang pada model pengembangan sebelumnya, pengembangan media gambar "Be a Scientist" dengan program Adobe Flash CS3 ini mengadaptasi model pengembangan Borg \& Gall dan model pengembangan Sugiyono. Ada 7 langkah yang digunakan sebagai langkah pengembangan media gambar "Be a Scientist" dengan program Adobe Flash CS3 dalam penelitian ini. Langkah-langkah tersebut adalah sebagai berikut:

Penelitian Pendahuluan

Penelitian pendahuluan ini adalah dengan melakukan survey ke tempat subjek penelitian. Analisis kebutuhan ini dilakukan agar dapat memperoleh data tentang media gambar yang digunakan guru, fungsi media gambar dan pendapat guru terhadap media gambar yang digunakannya dalam pembelajaran sejarah. Adanya tahap ini diharapkan nantinya peneliti mendapatkan informasi yang relevan terkait dengan pengembangan media gambar "Be $a$ Scientist" dengan program Adobe Flash CS3 untuk proses pembelajaran sejarah.

Tahap ini bertujuan untuk mendapatkan informasi yang relevan terkait dengan pengembangan media gambar "Be $a$ Scientist" dengan program Adobe Flash CS3 untuk proses pembelajaran Sejarah dengan melakukan analisis karakter siswa, studi pustaka, dan observasi dilapangan. Hal ini dilakukan untuk menemukan permasalahan yang ada yang terkait dengan pembelajaran sejarah.

Dina Fitriana, Pengembangan Media Gambar "Be a Scientist" dengan Program Adobe Flash CS3 untuk Pembelajaran Sejarah 
Perencanaan

Setelah melakukan analisis karakteristik peserta didik, studi pustaka dan observasi lapangan. Informasi yang telah dikumpulkan dijadikan sebagai acuan dalam mengembangkan media gambar " $B e \quad a$ Scientist" dengan program Adobe Flash CS3. Dalam tahap ini akan ditetapkan materi pokok, kompetensi yang ingin dicapai dan menyusun media gambar "Be a Scientist" dengan program Adobe Flash CS3.

Materi pokok yang akan disusun dalam media gambar "Be a Scientist" dengan program Adobe Flash CS3 ini adalah materi "Pengaruh agama dan kebudayaan Islam di Indonesia. Stuktur isi yang akan disusun dalam materi tersebut adalah sebagai berikut:(1) proses masuknya agama dan kebudayaan Islam ke Indonesia; (2) jalur-jalur penyebaran Islam di Indonesia; (3) kehidupan politik dan sosial-budaya masyarakat Indonesia pada masa perkembangan Islam; (4) Kerajaan-kerajaan tradisional bercorak Islam.

Materi tersebut digunakan dalam penyusunan media gambar "Be a Scientist" dengan program Adobe Flash CS3 karena materi ini memiliki muatan yang cukup banyak dengan waktu yang relatif sedikit. Tujuan pembelajaran materi ini dalam pengembangan media gambar "Be a Scientist" dengan program Adobe Flash CS3 disesuaikan dengan kompetensi inti dan kompetensi dasar yang ada pada kurikulum 2013.

\section{Produk Awal}

Tahap ini merupakan sebuah rangkaian proses untuk menghasilkan media gambar. Media gambar yang dikembangkan disesuaikan dengan cara kerja scientist, sehingga akan terwujudlah media gambar "Be a Scientist" dengan program Adobe Flash CS3. Penyusunan produk awal media gambar "Be a Scientist" dengan program Adobe Flash CS3 mecakup hal-hal sebagai berikut: pertama, Cover media yang menggambarkan cover media gambar "Be a Scientist" dengan program Adobe Flash CS3; kedua, judul yang menggambarkan materi yang akan dikaji dalam media gambar "Be a Scientist" dengan program Adobe Flash CS3; ketiga, tujuan yang akan dicapai peserta didik setelah mempelajari suatu materi dengan menggunakan media gambar "Be a Scientist" dengan program Adobe Flash CS3; keempat, Prosedur atau kegiatan yang bertujuan untuk meningkatkan kemampuan peserta didik dalam memperoleh konsep-konsep sejarah; kelima, penyajian materi; keenam, soal-soal latihan yang berhubungan dengan penemuan konsep-konsep oleh peserta didik.

\section{Validasi Desain}

Tahap ini merupakan tahap evaluasi produk yang dikembangkan dengan memvalidasi produk. Validasi produk ini dilakukan oleh ahli, yaitu ahli materi dan ahli media. Ahli-ahli tersebutlah yang nantinya akan menyatakan bahwa produk media gambar "Be a Scientist" dengan program Adobe Flash CS3 yang dikembangkan layak atau tidak.

\section{Revisi Desain}

Setelah desain produk divalidasi, maka akan diketahui kelemahannya. Kelemahan tersebut selanjutnya dijadikan penulis sebagai dasar untuk memperbaiki desain produk media gambar " $B e \quad a$ Scientist" dengan program Adobe Flash CS3.

\section{Ujicoba Produk}

Jika media gambar "Be a Scientist" dengan program Adobe Flash CS3 telah dinyatakan layak untuk dilakukan uji coba produk, maka peneliti akan melakukan uji coba produk. Uji coba akan dilakukan secara bertahap, yaitu dimulai dari uji coba satu-

Dina Fitriana, Pengembangan Media Gambar "Be a Scientist" dengan Program Adobe Flash CS3 untuk Pembelajaran Sejarah 
satu, uji coba kelompok kecil, dan uji coba lapangan.

\section{Revisi Desain}

Setelah dilakukan pengujian produk pada sampel. Maka akan dilakukan kembali revisi desain media gambar "Be a Scientist" dengan program Adobe Flash CS3. Adapun tujuan akhir dari revisi desain media gambar "Be a Scientist" dengan program Adobe Flash CS3 adalah mendapatkan produk akhir yang siap digunakan secara luas di lembaga pendidikan.

\section{Desain Ujicoba Produk}

Desain Ujicoba

Ujicoba dimaksudkan untuk memperoleh data secara lengkap yang dapat digunakan sebagai bahan revisi produk. Dalam penelitian dan pengembangan ini, juga memerlukan validasi ahli dan instrumen agar mendapatkan data yang valid. menyatakan agar diperoleh data yang valid maka, instrumen atau alat untuk mengevaluasinya harus valid dan reliabel. Aspek yang divalidasi dalam tahap uji model pengembangan ini meliputi beberapa hal sebagai berikut:

\section{Validasi ahli}

Validasi ahli merupakan proses untuk menilai suatu rancangan produk yang dilakukan oleh ahli. Para ahli yang dipilih harus memiliki pengetahuan sesuai dengan desain produk yang dikembangkan. Hal ini nantinya, diharapkan dapat membantu pengembang produk untuk melakukan revisi desain yang ia kembangkan.

Sebelum produk diujicobakan
kepada siswa, produk yang telah dikembangkan divalidasi oleh 1 orang ahli materi dan 1 ahli media. Validasi dari ahli ini penting dilakukan. Hal ini ini dilakukan untuk mendapatkan jaminan bahwa produk awal yang dikembangkan layak diujicobakan kepada peserta didik. selain itu juga untuk mengantisipasi kesalahan materi, kekurangan relevansi, ketepatan, keakuratan materi dan lain sebagainya. Validasi dari ahli berupa penilaian, komentar, dan saran perbaikan yang nantinya sangat diperlukan untuk mengetahui kelayakan produk yang dikembangkan.

Uji coba satu-satu (one to one evaluation)

Setelah produk dinyatakan layak oleh ahli materi dan ahli media, selanjutnya dilakukan uji coba instrumen yang nantinya akan digunakan sebagai alat evaluasi pada siswa ujicoba satu-satu (one to one evaluation). Tujuan uji coba satu-satu (one to one evolution) adalah untuk memperoleh bukti-bukti empirik tentang kelayakan produk awal secara terbatas. Dalam uji coba satu-satu, data yang ingin di temukan mengenai penilaian, komentar, hasil pengamatan, dan saran siswa yang kemudian disusun dan di analisis untuk merevisi produk.

Adapun proses uji coba satu-satu adalah sebagai berikut: pertama, menjelaskan kepada peserta didik mengenai rancangan media gambar "Be a Scientist" dengan program Adobe Flash CS3 dan ingin mengetahui bagaimana reaksi siswa terhadap materi dalam media gambar " $B e a$ Scientist” dengan program Adobe Flash CS3 tersebut; kedua, mengusahakan agar peserta didik rileks dan bebas dalam mengemukakan pendapatnya tentang media gambar " $B e a$ Scientist" dengan program Adobe Flash CS3; ketiga, menayangkan media gambar "Be a Scientist" dengan program Adobe Flash CS3 kepada peserta didik dan mempersilahkan peserta didik untuk melihat; keempat, membagikan lembar kuisioner tentang tanggapan peserta didik terhadap produk cerita bergambar yang sudah diujicobakan; Kelima, menganalisis informasi yang sudah dikumpulkan; Keenam, data dan informasi digunakan untuk merevisi media gambar " $\mathrm{Be} a$

Dina Fitriana, Pengembangan Media Gambar "Be a Scientist" dengan Program Adobe Flash CS3 untuk Pembelajaran Sejarah 
Scientist" dengan program Adobe Flash CS3.

Ujicoba Kelompok Kecil (Small Group Evaluation)

Tujuan uji coba kelompok kecil (small group evaluation) digunakan untuk mengumpulkan informasi yang dapat memperbaiki produk dalam revisi berikutnya. Prosedur uji coba kelompok kecil ini adalah sebagai berikut: Pertama, menjelaskan kepada peserta didik maksud dan tujuan dilakukannya uji coba; kedua, meminta peserta didik untuk mempelajari materi yang disajikan dalam media gambar "Be a Scientist" dengan program Adobe Flash CS3; ketiga, menayangkan media gambar "Be a Scientist" dengan program Adobe Flash CS3 kepada peserta didik dan mempersilahkan peserta didik untuk melihat; keempat, membagikan kuisioner tentang tanggapan peserta didik terhadap media gambar "Be a Scientist" dengan program Adobe Flash CS3 yang sudah diujicobakan; kelima, menganalisis data yang terkumpul; keenam, data dan informasi dari kegiatan tersebut kemudian direvisi kembali.

\section{Uji Coba Lapangan (Fiels Trial)}

Tujuan uji coba lapangan ini adalah untuk menentukan apakah produk yang dihasilkan sudah memiliki kelayakan dilihat dari sudut pandang peserta didik. Sudut pandang tersebut meliputi aspek kemudahan produk untuk dipelajari isinya dan aspek kemenarikan grafis. Prosedur pelaksanaan ujicoba lapangan ini adalah sebagai berikut:pertama, menjelaskan kepada peserta didik maksud dan tujuan dilakukannya uji coba; kedua, meminta peserta didik untuk mempelajari materi dan mengerjakan soal-soal yang ada pada media gambar "Be a Scientist" dengan program Adobe Flash CS3; ketiga, membagikan kuisioner tentang tanggapan peserta didik terhadap media gambar "Be a Scientist" dengan program Adobe Flash CS3; keempat, menganalisis data yang diperoleh.

Dari hasil ujicoba lapangan, materi dan soal-soal diperbaiki dan disempurnakan sehingga produk akhir media gambar "Be a Scientist" dengan program Adobe Flash CS3 terwujud dan siap digunakan.

\section{Subjek Uji Coba}

Subjek ujicoba atau responden yang terlibat dalam penelitian ini adalah peserta didik kelas X SMA N 1 Jetis. Pemilihan SMA N 1 Jetis ini dikarenakan pembelajaran Sejarah di kelas $X$ pada SMA ini menggunakan LKS sebagai media belajar. SMA N 1 jetis ini memiliki 7 kelas paralel pada kelas $X$ yang di bagi menjadi 4 kelas untuk IPA dan 3 kelas untuk IPS. Setiap kelas diisi dengan 30 peserta didik. Dalam penelitian ini jumlah hasil random yang menjadi subjek uji coba dengan sebaran sebagai berikut:pertama, uji coba satu-satu (one to one evaluation) sebanyak 5 peserta didik; kedua, uji coba kelompok kecil (small group evaluation) sebanyak 15 peserta didik; ketiga, uji coba lapangan (field trial) sebanyak 32 peserta didik.

Teknik dan Instrumen Pengumpulan Data Teknik Pengumpulan Data

Teknik pengumpulan data yang digunakan dalam penelitian ini adalah wawancara, observasi, penyebaran angket dan dokumentasi. Dengan teknik pengumpulan data tersebut, data yang diperoleh dalam penelitian ini merupakan data yang digunakan sebagai dasar untuk menetapkan kelayakan dari media gambar "Be a Scientist" dengan program Adobe Flash CS3. Data yang digunakan untuk menentukan kelayakan media gambar "Be a Scientist" dengan program Adobe Flash CS3 adalah sebagai berikut: (1) kelayakan aspek materi dari ahli materi; (2) kelayakan aspek media dari ahli media; (3) evaluasi dari

Dina Fitriana, Pengembangan Media Gambar "Be a Scientist" dengan Program Adobe Flash CS3 untuk Pembelajaran Sejarah 
aspek materi dan aspek media oleh guru Sejarah; (4) evaluasi dari aspek materi dan aspek media oleh peserta didik.

Instrumen Pengumpulan Data

Pada prinsipnya meneliti adalah melakukan pengukuran, maka harus ada alat ukur yang baik. Alat ukur dalam penelitian disebut dengan instrumen penelitian. Instrumen yang digunakan untuk mengumpulkan data pada penelitian pengembangan berupa lembar validasi ahli, angket, dan wawancara. Lembar validasi digunakan untuk mengukur kelayakan produk yang dikembangkan. Lembar angket dan wawancara digunakan untuk mengukur kelayakan produk yang dikembangkan dilihat dari isi materi, soal-soal dan aspek media baik menurut validator, guru dan peserta didik.

Pada kerangka prosedur pengembangan telah diuraikan tahap penyusunan media gambar "Be a Scientist" dengan program Adobe Flash CS3, selajutnya diperlukan validasi dari ahli media. Ahli media untuk menguji kelayakan media gambar " $B e \quad a$ Scientist" dengan program Adobe Flash CS3 yang telah dikembangkan agar layak diujikan dan layak digunakan oleh peserta didik. Harapan dari pengembangan media gambar "Be a Scientist" dengan program Adobe Flash CS3 ini dapat digunakan peserta didik dalam proses pembelajaran Sejarah.

Teknik Analisis data

Data hasil penelitian ini adalah berupa tanggapan ahli materi, ahli media, guru dan peserta didik terhadap kelayakan produk yang telah dikembangkan. Data berupa komentar, saran perbaikan dan hasil pengamatan peneliti selama proses ujicoba dianalisis secara deskriptif dan disimpulkan sebagai masukan untuk memperbaiki atau merevisi produk yang telah dikembangkan berupa data skor yang diperoleh melalui angket, dianalisis secara deskriptif kuantitatif dengan teknik persentase dan kategorisasi. Data tanggapan ahli materi, ahli media, guru dan peserta didik.

Langkah-langkah yang digunakan untuk menentukan kriteria kelayakan produk yang telah dikembangkan adalah sebagai berikut:

Data yang diperoleh dari lembar validasi dan lembar angket di cari rata-ratanya.

Dalam angket diberi lima pilihan untuk memberikan tanggapan tentang produk yang dikembangkan, yaitu sangat baik (5), baik (4), cukup (3), kurang (2), dan sangat kurang (1). Jika tanggapan peserta didik sangat baik pada salah satu butir pertanyaan, maka skor butir pertanyaan tersebut 5, demikian seterusnya. Untuk mencari skor rata-rata dalam memberikan penilaian terhadap produk yang telah dikembangkan digunakan rumus:

$\bar{x}_{i}=\frac{\sum x}{n}$

Keterangan:

$\bar{x}_{i} \quad:$ Skor rata-rata

$\sum \mathrm{x}$ : Jumlah skor

$\mathrm{N}$ : Jumlah responden.

Menggunakan penilaian acuan patokan (PAP) sebagai berikut:

Tabel 1. Konversi data

\begin{tabular}{|c|c|c|}
\hline Nilai & Interval Skor & $\begin{array}{c}\text { Data } \\
\text { Kualitatif }\end{array}$ \\
\hline $\mathbf{A}$ & $\mathrm{X}>\bar{X}_{\mathrm{i}}+1,8 \mathrm{Sb}_{\mathrm{i}}$ & Sangat Baik \\
\hline B & $\begin{array}{c}\bar{X}_{\mathrm{i}}+0.60 \mathrm{Sb}_{\mathrm{i}}<\mathrm{X} \\
\leq \bar{X}_{\mathrm{i}}+1,80 \mathrm{Sb}_{\mathrm{i}}\end{array}$ & Baik \\
\hline $\mathbf{C}$ & $\begin{array}{c}\bar{X}_{\mathrm{i}}-0.60 \mathrm{Sb}_{\mathrm{i}}<\mathrm{X} \leq \\
\bar{X}_{\mathrm{i}}+0,60 \mathrm{Sb}_{\mathrm{i}}\end{array}$ & Cukup \\
\hline D & $\begin{array}{c}\bar{X}_{\mathrm{i}}-1.80 \mathrm{Sb}_{\mathrm{i}}<\mathrm{X} \leq \\
\bar{X}_{\mathrm{i}}-0,60 \mathrm{Sb}_{\mathrm{i}}\end{array}$ & Kurang \\
\hline $\mathbf{E}$ & $\mathrm{X} \leq \bar{X}_{\mathrm{i}}-1,80 \mathrm{Sb}_{\mathrm{i}}$ & Sangat kurang \\
\hline
\end{tabular}

Berdasarkan rumus konversi data, maka setelah didapatkan data-data, untuk mengubahnya menjadi data kuantitatif, pada

Dina Fitriana, Pengembangan Media Gambar "Be a Scientist" dengan Program Adobe Flash CS3 untuk Pembelajaran Sejarah 
pengembangan ini diterapkan konversi data kedalam skala 100 sebagai berikut:

Skor $1=20$, Skor $2=40$, Skor $3=60$, Skor $4=80$, Skor $5=100$

Skor maksimal: 100

Skor Minimal: 20

$\bar{X}_{\mathrm{i}}=\frac{1}{2}(100+20)=60$

$\mathrm{Sb}_{\mathrm{i}}=\frac{1}{6}(100-20)=13,3$

Sehingga, diperoleh kriteria-kriteria penilaian sebagai berikut:

$$
\begin{aligned}
\text { Sangat baik } & =X>60+1,8 \times 13,3 \\
& =X>60+23,94 \\
& =X>83,94
\end{aligned}
$$

Baik $\quad=60+(0,60 \times 13,3)<X \leq$ 83,94

$=60+7,98<\mathrm{X} \leq 83,94$

$=67,98<X \leq 83,94$

Cukup $\quad=60-(0,60 \times 13,3)<X \leq$

67,98

$=60-7,98<X \leq 67,98$

$=52,2<\mathrm{X} \leq 67,98$

Kurang $\quad=60-(1,8 \times 13,3)<X \leq 52,2$

$=60-23,94<\mathrm{X} \leq 2,60$

$=36,06<X \leq 2,60$

Sangat kurang $=\mathrm{X}<3,06$

Dari perhitungan tersebut, maka diperoleh tabel kriteria penilaian sebagai berikut:

Tabel 2. Kriteria Penilaian

\begin{tabular}{ccc}
\hline Nilai & Interval Skor & $\begin{array}{c}\text { Data } \\
\text { Kualitatif }\end{array}$ \\
\hline A & $\mathrm{X}>83,94$ & Sangat Baik \\
B & $67,98<\mathrm{X} \leq$ & Baik \\
& 83,94 & \\
C & $52,2<\mathrm{X} \leq$ & Cukup \\
& 67,98 & \\
D & $36,06<\mathrm{X} \leq$ & Kurang \\
& 52,2 & \\
\hline
\end{tabular}

\begin{tabular}{ccc}
\hline E & X $<36,06$ & Sangat kurang \\
\hline & Selanjutnya & dengan
\end{tabular}

Selanjutnya dengan berpedoman pada tabel hasil konversi di atas, seluruh data data di konversi menjadi data kualitatif untuk menentukan kriteria kelayakan pada masing-masing aspek.

\section{Hasil Penelitian dan Pembahasan}

Pelaksanaan pengembangan media gambar "Be a Scientist" dengan program Adobe Flash CS3 untuk pembelajaran Sejarah kelas X SMA, diawali dengan melakukan prasurvey. Prasurvey dilaksanakan pada tanggal 23 juli 2013 dengan melakukan observasi sekolah dan wawancara kepada guru mata pelajaran sejarah. Prasurvey dilaksanakan untuk mendapatkan informasi mengenai berbagai hal yang terkait dengan proses pembelajaran di sekolah. Data hasil Prasurvey tersebut menjadi dasar bagi peneliti untuk melakukan analisis kebutuhan dalam kegiatan pembelajaran. peneliti kemudian menetapkan tujuan pembuatan media gambar "Be a Scientist", melakukan tinjauan terhadap standar isi untuk menetapkan Kompetensi Inti (KI), Kompetensi Dasar (KD), Indikator, pengumpulan referensi berupa foto atau gambar, penulisan materi, dan pembuatan desain media pembelajaran.

Untuk mendapatkan kualitas produk yang baik, maka produk media pembelajaran yang dikembangkan sebelum dilakukan uji coba lapangan terlebih dahulu divalidasi oleh ahli materi dan ahli media, serta evaluasi guru mata pelajaran sejarah. Untuk mendapatkan data validasi oleh ahli materi, dilaksanakan 2 kali pertemuan. Pertemuan pertama pada tanggal 4 Maret 2014 dan kemudian mendapat penilaian pada tanggal 10 maret 2014. Penilaian pertama oleh ahli materi, langkah-langkah scientist masih belum muncul sehingga perlu diperbaiki. Setelah peneliti memperbaiki, pertemuan kedua dengan ahli materi kembali

Dina Fitriana, Pengembangan Media Gambar "Be a Scientist" dengan Program Adobe Flash CS3 untuk Pembelajaran Sejarah 
dilaksanakan pada tanggal 21 Maret 2014. Selanjutnya, pada tanggal 28 Maret 2014, lembar validasi di isi dan ditandatangani oleh ahli media. Media Gambar "Be a Scientist" dengan program Adobe Flash CS3 untuk pembelajaran sejarah kelas X SMA dinyatakan layak untuk di ujicobakan.

Untuk mendapatkan data Validasi oleh ahli media, dilaksanakan 3 kali pertemuan. Pertemuan pertama dilaksanakan pada tanggal 7 Maret 2014 kemudian mendapat penilaian tanggal 14 maret 2014 . Penilaian oleh ahli media berupa perbaikan terhadap kisi instrumen daftar penilaian terlalu sedikit. Pertemuan kedua dilaksanakan pada tanggal 21 Maret 2014. Media mendapat penilaian pada tanggal 28 Maret 2014. Media gambar "Be a Scientist" sudah dinyatakan layak dengan catatan terdapat kekurangan pada media pembelajaran berupa belum di buatnya Autorun, profil seharusnya diletakkan paling belakang, perlu adanya pencantuman KI. Setelah melakukan perbaikan, pertemuan ketiga dilaksanakan pada tanggal 1 April 2014. Pada pertemuan tersebut, penilaian terhadap media gambar "Be a Scientist" dinyatakan layak oleh ahli media.

Evaluasi oleh guru sejarah dilaksanakan pada tanggal 24 Maret 2014. Penilaian terhadap media gambar "be a scientist" dengan program Adobe Flash CS3 telah sesuai dengan kompetensi yang harus dicapai siswa dan layak untuk diujicobakan. Selanjutnya, dilaksanakan uji coba satu-satu (one to one evaluation) pada tanggal 25 Maret 2014 terhadap 5 peserta didik kelas X IPS $^{3}$ yang selanjutnya dibagikan angket. Ujicoba kelompok kecil (Small Group Evaluation) pada tanggal 29 Maret 2014 terhadap 15 peserta didik kelas X IPA ${ }^{2}$ yang selanjutnya dibagikan angket.

Setelah mendapatkan penilaian validasi dari ahli materi, validasi ahli media, guru mata pelajaran sejarah, serta angket uji coba satu-satu (one to one evaluation) dan uji coba kelompok kecil (Small Group Evaluation) langkah selanjutnya melakukan analisis. Analisis dilaksanakan untuk mengetahui tanggapan terhadap media pembelajaran yang dikembangkan, serta dilakukan revisi sesuai saran demi penyempurnaan produk yang dikembangkan.

Uji coba lapangan dilaksanakan 2 kali pertemuan. Pertemuan pertama dilaksanakan pada tanggal 2 April 2014 dan pertemuan kedua dilaksanakan pada 5 April 2014. Uji coba di laksanakan pada kelas X IPA $^{3}$ sebanyak 32 peserta didik. Pada pertemuan pertama, kegiatan yang dilaksanakan adalah penyampaian materi proses masuknya agama dan kebudayaan Islam ke Indonesia serta materi saluransaluran penyebaran Islam. Pada pertemuan kedua, kegiatan yang dilaksanakan penyampaian materi kehidupan politik sosial-budaya masyarakat Indonesia pada masa perkembangan Islam serta meteri kerajaan-kerajaan tradisional bercorak Islam di Indonesia. Setelah kegiatan ujicoba selesai, dilakukan penyebaran angket untuk di isi oleh peserta didik.

Selanjutnya, data hasil angket validasi ahli materi, angket ahli media, guru sejarah, uji coba lapangan dianalisis untuk mengetahui sejauh mana kelayakan pengembangan media gambar "Be a Scientist" dengan program Adobe Flash CS3 untuk pembelajaran Sejarah kelas X SMA yang dikembangkan sebagai media pembelajaran.

\section{Hasil Penelitian dan Pembahasan}

Hasil Uji Coba produk

Hasil Validasi oleh Ahli Materi

Berdasarkan data validasi ahli materi, skor rata-rata yang diperoleh dari penilaian ahli materi sebesar 3,67. Kemudian skor rata-rata tersebut di konversikan kedalam skala 100 dan memperoleh nilai sebesar 73,40. Untuk

Dina Fitriana, Pengembangan Media Gambar "Be a Scientist" dengan Program Adobe Flash CS3 untuk Pembelajaran Sejarah 
selanjutnya dikonversikan ke dalam data kualitatif sesuai dengan ktiteria peniliaan. Sehingga, dapat diketahui bahwa menurut ahli materi, media gambar "Be a Scientist" dengan program Adobe Flash CS3 untuk pembelajaran sejarah pada kelas X SMA secara keseluruhan termasuk dalam kategori baik.

\section{Hasil Validasi oleh Ahli Media}

Berdasarkan validasi ahli media, skor rata-rata yang diperoleh dari penilaian ahli media sebesar 3,8. Kemudian skor rata-rata tersebut di konversikan kedalam skala 100 dan memperoleh nilai sebesar 76. Untuk selanjutnya dikonversikan ke dalam data kualitatif sesuai dengan ktiteria peniliaan. Sehingga, dapat diketahui bahwa menurut ahli media, media gambar "Be a Scientist" dengan program Adobe Flash CS3 untuk pembelajaran sejarah pada kelas X SMA secara keseluruhan termasuk dalam kategori baik.

Hasil Evaluasi oleh Guru Sejarah

Berdasarkan data evaluasi oleh guru, skor rata-rata yang diperoleh dari penilaian Guru pada aspek materi sebesar 4,13 dan aspek media sebesar 4,3. Kemudian skor rata-rata tersebut di konversikan kedalam skala 100 dan memperoleh skor 82,5 pada aspek materi dan skor 86 pada aspek media. Untuk selanjutnya dikonversikan ke dalam data kualitatif sesuai dengan ktiteria peniliaan. Sehingga, dapat diketahui bahwa menurut guru sejarah, media gambar "Be a Scientist" dengan programAdobe Flash CS3 untuk pembelajaran sejarah pada kelas $\mathrm{X}$ SMA pada aspek materi secara keseluruhan termasuk dalam kategori baik. Sedangkan, pada aspek media secara keseluruhan termasuk dalam kategori Sangat baik.

Hasil Uji Coba Peserta Didik

Hasil Uji Coba Satu-Satu (One to One Evaluation).

Berdasarkan data hasil ujicoba satusatu (one to one evaluation), skor rata-rata yang diperoleh dari penilaian peserta didik pada aspek materi sebesar 4,38 dan aspek media sebesar 4,48. Kemudian skor rata-rata tersebut di konversikan kedalam skala 100 dan memperoleh skor 87,6 pada aspek materi dan skor 89,6 pada aspek media. Untuk selanjutnya dikonversikan ke dalam data kualitatif sesuai dengan ktiteria peniliaan. Sehingga,dapat diketahui bahwa menurut peserta didik, media gambar "Be a Scientist" dengan programAdobe Flash CS3 untuk pembelajaran Sejarah pada kelas X SMA pada aspek materi dan aspek media secara keseluruhan termasuk dalam kategori Sangat baik.

Hasil Uji Coba Kelompok Kecil (Small Group Evaluation).

Berdasarkan data hasil ujicoba kelompok (small group evaluation), skor rata-rata yang diperoleh dari penilaian peserta didik pada aspek materi sebesar 4,12 dan aspek media sebesar 4,22. Kemudian skor rata-rata tersebut di konversikan ke dalam skala 100 dan memperoleh skor 82,4 pada aspek materi dan skor 84,4 pada aspek media. Untuk selanjutnya dikonversikan ke dalam data kualitatif sesuai dengan ktiteria peniliaan. Sehingga, dapat diketahui bahwa menurut peserta didik, media gambar "Be a Scientist" dengan program Adobe Flash CS3 untuk pembelajaran sejarah pada kelas $\mathrm{X}$ SMA pada aspek materi secara keseluruhan termasuk kategori baik. Sedangkan, pada aspek media secara keseluruhan termasuk dalam kategori Sangat baik.

Hasil Uji Coba Lapangan (Field Trial).

Berdasarkan data ujicoba lapangan

(Field Trial), skor rata-rata yang diperoleh dari penilaian pesera didik pada aspek materi sebesar 4,075 dan aspek media sebesar 4,053. Kemudian skor rata-rata tersebut di konversikan ke dalam skala 100 dan memperoleh skor 81,5 pada aspek materi dan skor 81,06 pada aspek media.

Dina Fitriana, Pengembangan Media Gambar "Be a Scientist" dengan Program Adobe Flash CS3 untuk Pembelajaran Sejarah 
Untuk selanjutnya dikonversikan ke dalam data kualitatif sesuai dengan kriteria penilaian. Sehingga, dapat diketahui bahwa menurut peserta didik, media gambar "Be a Scientist" dengan programAdobe Flash CS3 untuk pembelajaran sejarah pada kelas X SMA pada aspek materi dan aspek media secara keseluruhan termasuk dalam kategori baik.

\section{Analisis Kelayakan Produk}

Berdasarkan data hasil ujicoba baik dari aspek materi maupun media yang diperoleh selanjutnya dihitung total dan rataratanya. Hasil rata-rata dikonversikan ke skala 100 kemudian disesuaikan dengan kriteria Penilaian. Hal ini dilakukan untuk mengetahui kualitas media menurut peserta didik. Hasil analisis data evaluasi peserta didik pada aspek materi dan aspek media adalah sebagai berikut:

Aspek Materi

Tabel 3. Analisis Kelayakan Produk Pada Aspek MAteri

\begin{tabular}{clccc}
\hline No & $\begin{array}{c}\text { Subjek } \\
\text { penelitian }\end{array}$ & $\begin{array}{c}\text { Skor } \\
\text { Rata- } \\
\text { rata }\end{array}$ & $\begin{array}{c}\text { Nilai } \\
\text { konversi } \\
\text { skala } \\
\mathbf{1 0 0}\end{array}$ & Kategori \\
\hline 1 & Ahli Materi & 3,67 & $\mathrm{~B}$ & Baik \\
2 & Guru & 4,13 & $\mathrm{~B}$ & Baik \\
3 & Peserta & 4,115 & $\mathrm{~B}$ & Baik \\
& Didik & 11,915 & $\mathrm{~B}$ & Baik \\
\hline Total & 3,97 & $\mathrm{~B}$ & Baik \\
\hline \multicolumn{2}{c}{ Rata-rata } & $\mathrm{B}$ & Baik \\
\hline $\begin{array}{c}\text { Skor Konversi } \\
\text { Skala 100 }\end{array}$ & 79,4 & & \\
\hline
\end{tabular}

Aspek Media

Tabel 4. Analisis Kelayakan Produk Pada Aspek Media

\begin{tabular}{lcccc}
\hline No & $\begin{array}{c}\text { Subjek } \\
\text { penelitian }\end{array}$ & $\begin{array}{c}\text { Skor } \\
\text { Rata- } \\
\text { rata }\end{array}$ & $\begin{array}{c}\text { Nilai } \\
\text { konversi } \\
\text { skala }\end{array}$ & Kategori \\
\hline
\end{tabular}

\begin{tabular}{|c|c|c|c|c|}
\hline & & \multicolumn{3}{|c|}{100} \\
\hline 1 & Ahli Media & 3,8 & $\mathrm{~B}$ & Baik \\
\hline 2 & Guru & 4,3 & A & $\begin{array}{c}\text { Sangat } \\
\text { Baik }\end{array}$ \\
\hline 3 & $\begin{array}{l}\text { Peserta } \\
\text { didik }\end{array}$ & 4,153 & B & Baik \\
\hline & Total & $\begin{array}{c}12,25 \\
3\end{array}$ & B & Baik \\
\hline & Rata-Rata & 4,08 & B & Baik \\
\hline & $\begin{array}{l}\text { or Konversi } \\
\text { Skala } 100\end{array}$ & 81,6 & B & Baik \\
\hline
\end{tabular}

Dari tabel analisis data data keyakan produk, skor rata-rata yang diperoleh pada aspek materi sebesar 3,97 dan aspek media sebesar 4,08. Kemudian skor rata-rata tersebut di konversikan kedalam skala 100 dan memperoleh skor 79,4,5 pada aspek materi dan skor 81,6 pada aspek media. Sehingga, dapat diketahui bahwa media gambar "Be a Scientist" dengan program Adobe Flash CS3 untuk pembelajaran sejarah pada kelas X SMA pada aspek materi dan aspek media secara keseluruhan termasuk dalam kategori baik.

\section{Penutup \\ Simpulan}

Kesimpulan dari penelitian pengembangan ini yaitu: pertama, untuk menghasilkan media gambar "be a scientist" dengan program Adobe Flash CS3 untuk pembelajaran sejarah kelas $\mathrm{X}$ SMA dilaksanakan sesuai dengan metode pengembangan yang diadaptasi dari sistematik pengembangan yang dikembangkan Borg \&Gall dan Sugiyono. Sistematik pengembangan tersebut meliputi penelitian pendahuluan, perencanaan, produk awal, validasi desain, revisi desain, ujicoba produk, revisi desain, dan produk jadi; kedua, kelayakan pengembangan media media gambar "be a scientist" dengan program Adobe Flash CS3 untuk pembelajaran sejarah kelas X SMA pada materi pengaruh agama dan kebudayaan

Dina Fitriana, Pengembangan Media Gambar "Be a Scientist" dengan Program Adobe Flash CS3 untuk Pembelajaran Sejarah 
Islam di Indonesia dinyatakan layak untuk digunakan sebagai media pembelajaran di kelas maupun sebagai sumber belajar mandiri siswa. Hal ini dapat diuraikan sebagai berikut: (1) pada aspek materi penilaian layak dengan skor 79,4 dan kategori penilaian "B" (Baik). (2) pada aspek media penilaian layak dengan skor 81,6 dan kategori penilaian "B" (Baik).

\section{Saran}

Saran yang dapat disampaikan oleh peneliti berdasarkan hasil penelitian ini adalah sebagai berikut: (1) bagi Siswa, hasil penelitian ini diharapkan dapat dijadikan sebagai sumber belajar bagi siswa agar selalu termotivasi untuk terus belajar sejarah khususnya materi pengaruh agama dan kebudayaan Islam di Indonesia. (2) bagi guru dan instansi pendidikan, hasil penelitian ini diharapkan dapat dijadikan sebagai bahan pertimbangan bagi guru untuk selalu berinovasi dalam mengembangkan media pembelajaran sejarah.

\section{Ucapan Terima Kasih}

Dalam kesempatan ini, penulis mengucapkan terima kasih kepada berbagai pihak yang telah membantu terlaksananya penelitian ini. Tak lupa, penulis juga menyampaikan ucapan terima kasih kepada dewan redaksi Jurnal Istoria terbitan Pendidikan Sejarah, Fakultas Ilmu Sosial, Universitas Negeri Yogyakarta atas kesempatan yang diberikan sehingga tulisan ini dapat dipublikasikan pada edisi Maret 2015.

\section{Daftar Pustaka}

AzharArsyad. (2011). Media pembelajaran. Jakarta: PT Grafindo Persada.

Kasfur Anwar \& Hendra Harmi. (2011). Perencanaan sistem pembelajaran kurikulum tingkat satuan pendidikan (KTSP). Alfabeta: Bandung.

Kemdikbud. (2013). Konsep pendekatan scientific. Jakarta: Kementrian Pendidikan dan Kebudayaan.

Nursid sumaatmadja. (2008). Konsep dasar IPS. Jakarta: Universitas Terbuka.

Peraturan Menteri Pendidikan dan Kebudayaan(Permendikbud)

Republik Indonesia nomor 65 tahun 2013 tentang standar proses untuk satuan pendidikan dasar dan menengah.

Peraturan Pemerintah (PP) Republik Indonesia nomor 17 tahun 2010 tentang pengelolaan dan penyelenggaraan pendidikan.

Suhartono W. Pranoto. (2010). Teori \& Metodologi Sejarah. Yogyakarta: Graha Ilmu.

Trianto. (2012). Mendesain Model Pembelajaran Inovatif-progresif. Jakarta: Kencana Prenada Media Group.

Undang-Undang Republik Indonesia No.20 tahun 2003 tentang Sistem Pendidikan Nasional.

Zainal Aqib. (2013). Model-model, media dan strategi pembelajaran kontekstual (inovatif). Bandung: CV. Yrama Widya. 